\title{
KAJIAN SEA SURFACE TEMPERATURE (SST), SOUTHERN OSCILLATION INDEX (SOI) DAN DIPOLE MODE PADA KEGIATAN PENERAPAN TEKNOLOGI MODIFIKASI CUACA DI PROPINSI RIAU DAN SUMATERA BARAT JULI - AGUSTUS 2009
}

\author{
Djazim Syaifullah ${ }^{1}$
}

\begin{abstract}
Study of sea surface temperature, SOI and dipole mode indices (DMI), was held to see global influence conditions of cloud growth in Kotapanjang and Singkarak catchment on the cloud seeding project from July to August 2009. The data used in this study was sea surface temperature (SST), taken from University Corporation Athmospheric research (UCAR). The sea surface temperature was analysed in Nino12 regions and Western region of Sumatra. Based on the analysis shows that during cloud seeding period the sea surface temperature anomaly for the four regions of Niño (Niño2 Niño3, Niño34 and Niño4) is positive, while in the western of Sumatra in general since the beginning of April 2009 the sea temperature was higher than normal. This indicates that during cloud seeding period global condition has entered a stage of Elnino, although not so strong. The soi is generally in the range of normal. The analysis showed that during the cloud seeding period either watershed atmospheric conditions dry enough and very difficult to get a potential cloud for sowing.
\end{abstract}

\section{Intisari}

\begin{abstract}
Kajian suhu muka laut, SOI dan Dipole Mode Index (DMI) telah dilakukan untuk melihat pengaruh global terhadap kondisi pertumbuhan awan di daerah DAS Kotapanjang dan Singkarak pada pelaksanaan Teknologi Modifikasi Cuaca (TMC) Juli - Agustus 2009. Data yang dipakai dalam penelitian ini adalah data Sea Surface Temperature (SST) yang diambil dari University Corporation for Athmospheric Research (UCAR). suhu muka laut yang dianalisis adalah daerah Nino dan daerah Sumatera bagian barat. Dari hasil analisis terlihat bahwa selama kegiatan TMC nilai anomali SST untuk keempat daerah Nino (Nino12, Nino3, Nino34 dan Nino4) adalah positif, hal ini menunjukkan bahwa selama kegiatan TMC kondisi global sudah memasuki fase EINino meskipun belum begitu kuat. Sedangkan di wilayah Sumatera bagian barat secara umum sejak awal bulan April 2009 nilai suhu muka laut berada di atas rerata dari normalnya (anomali positif). Dilihat dari nilai SOI secara umum berada pada kisaran normal. Hasil analisis menunjukkan bahwa selama kegiatan TMC kondisi atmosfer kedua DAS cukup kering dan sangat sulit untuk mendapatkan awan-awan yang potensial untuk disemai.
\end{abstract}

Kata kunci : Sea Surface Temperature, SOI, DMI, Teknologi Modifikasi cuaca

\section{PENDAHULUAN}

Kondisi aliran masuk (inflow) di Danau Singkarak dan Waduk Kotapanjang memasuki musim kemarau 2009 semakin menyusut drastis karena kurangnya curah hujan. Apabila tidak diantisipasi secepatnya maka PLTA Singkarak dan PLTA Waduk Kotapanjang yang mengandalkan debit air akan semakin kritis karena ketersediaan listrik saat ini sudah tidak mencukupi untuk melayani konsumen. Untuk itu direktur PT. PLN (Presero)

${ }_{1}$ Peneliti Madya - UPT Hujan Buatan, BPPT, Thamrin No. 8 Jakarta, email djazim@yahoo.com
Luar Jawa Madura Bali meminta dilakukan penerapan Teknologi Modifikasi Cuaca untuk mengatasi masalah krisis air di kedua waduk.

Penerapan Teknologi Modifikasi Cuaca (TMC) telah dilakukan di DAS Kotapanjang dan DAS Singkarak pada selang antara bulan Juli sampai dengan Agustus 2009, dengan tujuan untuk menambah inflow yang masuk ke PLTA Waduk Kotapanjang dan PLTA Danau Singkarak. Pelaksanaan kegiatan TMC dilakukan dari tanggal 16 Juli hingga 4 Agustus 2009 di wilayah DAS Kotapanjang dan DAS Singkarak. Selama pelaksanaan TMC tersebut kondisi global di amati 
secara seksama dari berbagai sumber data. Kondisi global yang diamati diantaranya adalah kondisi Sea Surface Temperature (SST) wilayah Nino, SST wilayah Sumatera bagian barat (Samudera Indonesia bagian Timur), kondisi Southern Oscillation Index (SOI) dan kondisi Dipole Mode.

Hasil pelaksanaan TMC berupa aliran permukaan (surface runoff) yang masuk ke dalam waduk baik waduk Kotopanjang maupun Danau Singkarak terlihat kurang begitu maksimal, hal ini dikarenakan kondisi atmosfer yang kurang mendukung terhadap proses pembentukan maupun pertumbuhan awan sehingga jumlah keberadaan awan potensial di semai kecil. Kondisi atmosfer yang kurangmendukung disebabkan oleh beberapa faktor yaitu faktor lokal dan faktor global. Tulisan ini akan menganalisis kondisi global pada saat kegiatan TMC tersebut dan melihat pengaruhnya terhadap kondisi atmosfer di daerah target.

\subsection{Sea Surface Temperature}

Suhu muka laut (Sea surface Temperature SST) di perairan Indonesia sebagai indeks banyaknya uap air pembentuk awan di atmosfer (Kadarsah). Jika suhu muka laut dingin uap air di atmosfer menjadi berkurang, sebaliknya jika suhu muka laut panas uap air di atmosfer banyak. Pola suhu muka laut di Indonesia secara umum mengikuti gerak tahunan matahari. Suhu muka laut di Samudera Hindia mempunyai rentang perubahan yang cukup lebar yaitu minimum berkisar $26.0^{\circ} \mathrm{C}$ pada bulan Agustus hingga maksimum berkisar $31.5^{\circ} \mathrm{C}$ pada bulan Febrauari - Maret. Wilayah perairan lainnya umumnya mempunyai rentang perubahan lebih sempit yaitu berkisar $29.0^{\circ} \mathrm{C}$ hingga $31.5^{\circ} \mathrm{C}$ dan waktu terjadinya minimum dan maksimumnya tidak sama disetiap perairan.

\subsubsection{SST daerah Nino}

Data daerah Nino34 dipilih sebagai data untuk dianalisis dengan alasan bahwa daerah tersebut mempunyai respon yang baik terhadap fenomena menghangatnya suhu muka laut di timur (Peru) dan di barat (Pasifik Barat) serta mempunyai korelasi yang cukup kuat terhadap nilai SOI, (Syaifullah D dan Djoko G, 1999). Disamping itu nilai anomali SST di kawasan ini juga mempunyai hubungan yang cukup erat dengan tingkat kekeringan di wilayah Indonesia.

Daerah Nino1.2 berada di $0^{0} \sim 10^{\circ} \mathrm{S}$ dan $90^{\circ} \mathrm{W} \sim 80^{\circ} \mathrm{W}$, daerah Nino3 di $5^{\circ} \mathrm{N} \sim 5^{\circ} \mathrm{S}$ dan $150^{\circ} \mathrm{W} \sim 90^{\circ} \mathrm{W}$, daerah Nino4 berada di $5^{\circ} \mathrm{N} \sim 5^{\circ} \mathrm{S}$ dan $160^{\circ} \mathrm{E} \sim 150^{\circ} \mathrm{W}$, sementara daerah Nino34 merupakan interseksi dari Nino3 dan Nino4 yang berada di daerah $5^{\circ} \mathrm{N} \sim 5^{\circ} \mathrm{S}$ dan $170^{\circ} \mathrm{E} \sim 120^{\circ} \mathrm{E}$.
Gambar 1 di bawah ini mengilustrasikan posisi dari daerah-daerah tersebut.

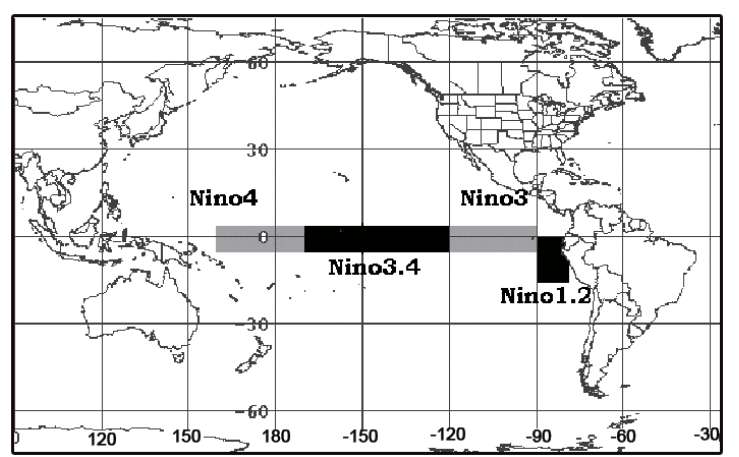

Gambar 1. Lokasi pengamatan SST daerah Nino

\subsubsection{SST daerah Sumatera Barat}

Peran laut dalam memproduksi uap air menjadi sangat penting, dan mempunyai jarak dekat dalam rangkaian proses pembentukan hujan. Khususnya untuk wilayah Sumatra Barat, lautan India adalah lautan di sekitarnya yang paling dekat. Dalam penelitian ini akan dicoba untuk melihat pengaruh lautan terdekat dengan wilayah DAS Kotopanjang dan DAS Singkarak terhadap kondisi curah hujannya. Daerah yang dipilih adalah Samudera Indonesia bagian sebelah barat Sumatera, seperti terlihat pada Gambar 2 berikut ini.

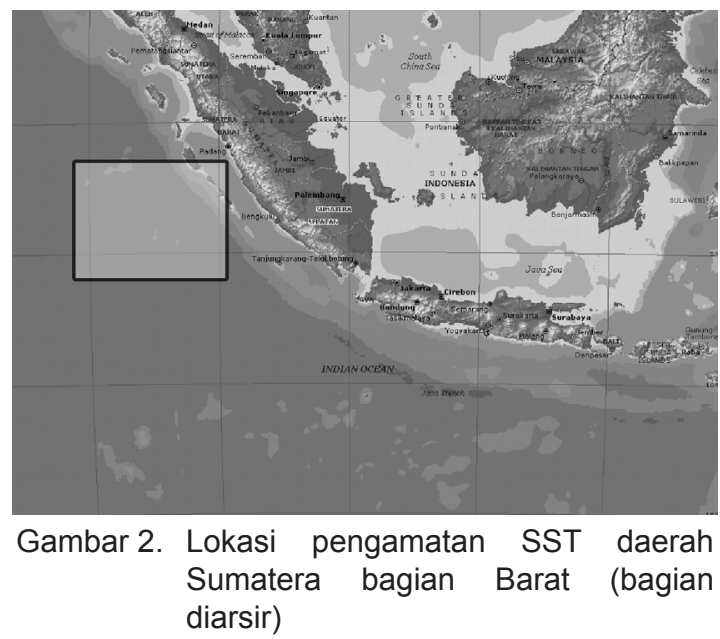

Gambar 2 menunjukkan lokasi pengamatan nilai SST wilayah Sumatera Bagian Barat yang berdekatan dengan wilayah DAS Kotopanjang dan DAS Singkarak. Daerah pengamatan (seperti yang diarsir) mencakup luasan dengan batas-batas : $0.5^{\circ} \mathrm{LS} \sim 4.5^{\circ} \mathrm{LS}$ dan $94.5^{\circ} \mathrm{BT} \sim 99.9^{\circ} \mathrm{BT}$.

\subsection{Southern Oscillation Index (SOI)}

Southern Oscillation Index (SOI) merupakan salah satu ukuran fluktuasi skala besar antara tekanan udara yang terjadi di barat Pasifik dengan 
di timur Pasifik wilayah tropis selama episode El Niño dan La Niña. Indeks ini telah dihitung berdasarkan perbedaan anomali tekanan udara antara Tahiti dan Darwin, Australia. Salah satu metode untuk menghitung nilai SOI dikenalkan oleh Bureau of Meteorology Australia (BOM) menggunakan metode Troup yang menghitung perbedaan standar anomali suhu muka laut ratarata antara Tahiti dan Darwin.

$$
S O I=\frac{\left[P_{\text {diff }}-P_{\text {diffuw }}\right]}{S D\left(P_{\text {diff }}\right)}
$$

Dimana :

$\left.\mathrm{P}_{\text {diff }}=(\text { tekanan } \mathrm{msl})_{\text {Tahititi }}(\text { tekanan } \mathrm{msl})_{\text {Darwin }}\right)$,

$\mathrm{P}_{\text {diffav }}^{\text {diff }}=$ rerata dari $P_{\text {diff }}$ jangka waktu panjang

$S D\left(P_{\text {diff }}\right)=$ standard deviasi dari $P_{\text {diff' }}$

Jika nilai SOI negatif maka tekanan di Tahiti relatif lebih kecil dibandingkan dengan tekanan di Darwin. Kondisi ini antara lain menyebabkan; bergesernya kolam hangat dari Pasifik Barat ke Pasifik Timur; terjadi pertumbuhan awan di Pasifik Timur di atas normalnya; terjadi kekeringan di Pasifik Barat terutama di Indonesia Timur karena suplai uap air bergeser ke timur dan lain-lain. Fenomena ini yang disebut dengan fenomena ElNino. Jika nilai SOI positif maka keadaan akan sebaliknya dan fenomena ini dikenal dengan fenomena La-Nina. Nilai SOI yang dianalisis dalam tulisan ini adalah Equatorial SOI (antara tekanan mmsl wilayah Indonesia dengan wilayah Pasifik Timur) dan Darwin-Tahiti SOI. Nilai SOI yang kadang positif dan kadang negatif memberi pengertian bahwa kejadian atau fenomena El-Nino maupun La-Nina mempunyai perulangan.

\subsection{Dipole Mode}

Dipole Mode merupakan fenomenayang mirip dengan EI Nino Southern Oscilation (ENSO) tetapi terjadi di wilayah Samudera Hindia. Dipole Mode merupakan intreraksi laut - atmosfer di Samudera Hindia yang dihitung dari nilai perbedaan (selisih) anomali suhu muka laut perairan pantai timur Afrika dengan perairan di sebelah barat Sumatera. Peristiwa ini ditandai dengan adanya perbedaan anomali suhu muka laut (sea surface temperature - SST) antara Samudera Hindia tropis bagian Barat $\left(50^{\circ} \mathrm{E}-70^{\circ} \mathrm{E}, 10^{\circ} \mathrm{N}-10^{\circ} \mathrm{S}\right)$ dengan Samudera Hindia tropis bagian Timur $\left(90^{\circ} \mathrm{E}-110^{\circ} \mathrm{E}, 10^{\circ} \mathrm{E}-\right.$ Equator), seperti terlihat pada gambar 3 .

Tahapan Siklus Dipole Mode adalah sebagai berikut : Pertama, Muncul anomali SST negatif di sekitar selat Lombok hingga selatan Jawa pada bulan Mei - Juni, bersamaan terjadi anomali angin tenggara yang lemah di sekitar Jawa dan Sumatera.

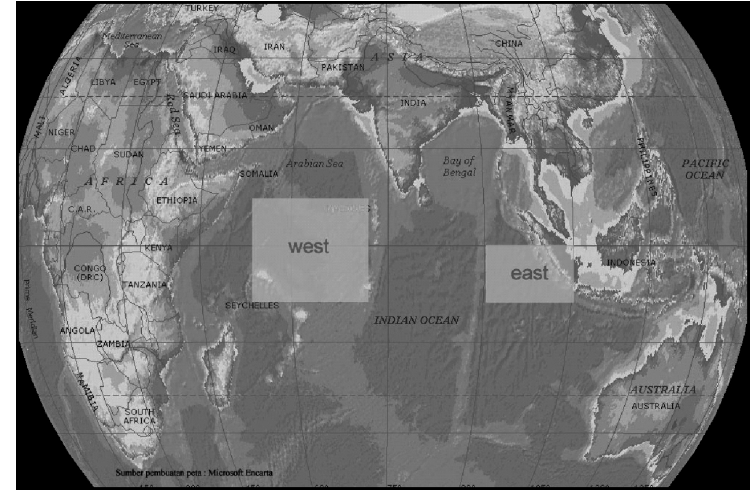

Gambar 3. Lokasi pengamatan Dipole Mode

Kedua, Anomali terus menguat (Juli - Agustus) dan meluas sampai ke ekuator di sepanjang pantai selatan Jawa hingga pantai barat Sumatera. Kondisi diatas dibarengi munculnya anomali positif SST di Samudera Hindia bagian barat. Adanya dua kutub di Samudera Hindia ekuator ini, semakin memperkuat anomali angin tenggara di sepanjang ekuator dan pantai barat Sumatera. Ketiga, Biasanya siklus mencapai puncaknya pada bulan Oktober, dan selanjutnya menghilang dengan cepat pada bulan November - Desember.

Beberapa riset menentukan sebuah indeks untuk mempelajari fenomena dipole mode ini, yang disebut dengan Dipole Mode Index (DMI). DMI didefinisikan sebagai selisih anomali SST di Samudera Hindia Bagian Barat dengan wilayah Samudera Hindia Bagian Timur seperti pada gambar 3.

Jika nilai DMI positif (Dipole Mode Positif), secara umum curah hujan di wilayah Indonesia bagian barat akan berkurang. Sedangkan jika nilai DMI negatif (Dipole Mode Negatif), maka curah hujan di wilayah Indonesia bagian barat secara umum akan bertambah.

\section{HASIL DAN PEMBAHASAN}

Dari hasil analisis akan ditunjukkan kondisi suhu muka laut (SST) daerah Nino selama kegiatan TMC berlangsung, kondisi nilai Southern Oscillation Index (SOI) dan nilai Dipole Mode Index dan akan dilihat pengaruhnya terhadap hujan yang dihasilkan di daerah target TMC (DAS Kotopanjang dan DAS Singkarak).

\subsection{Suhu Muka Laut Daerah Nino}

Seperti dijelaskan di muka bahwa daerah Nino mempunyai respon yang baik terhadap fenomena menghangatnya suhu muka laut di wilayah Peru dan di Pasifik Barat yang dikenal dengan fenomena EINino. Pengamatan dilakukan terhadap keempat daerah Nino (Nino12, Nino3, Nino34 dan Nino4). 


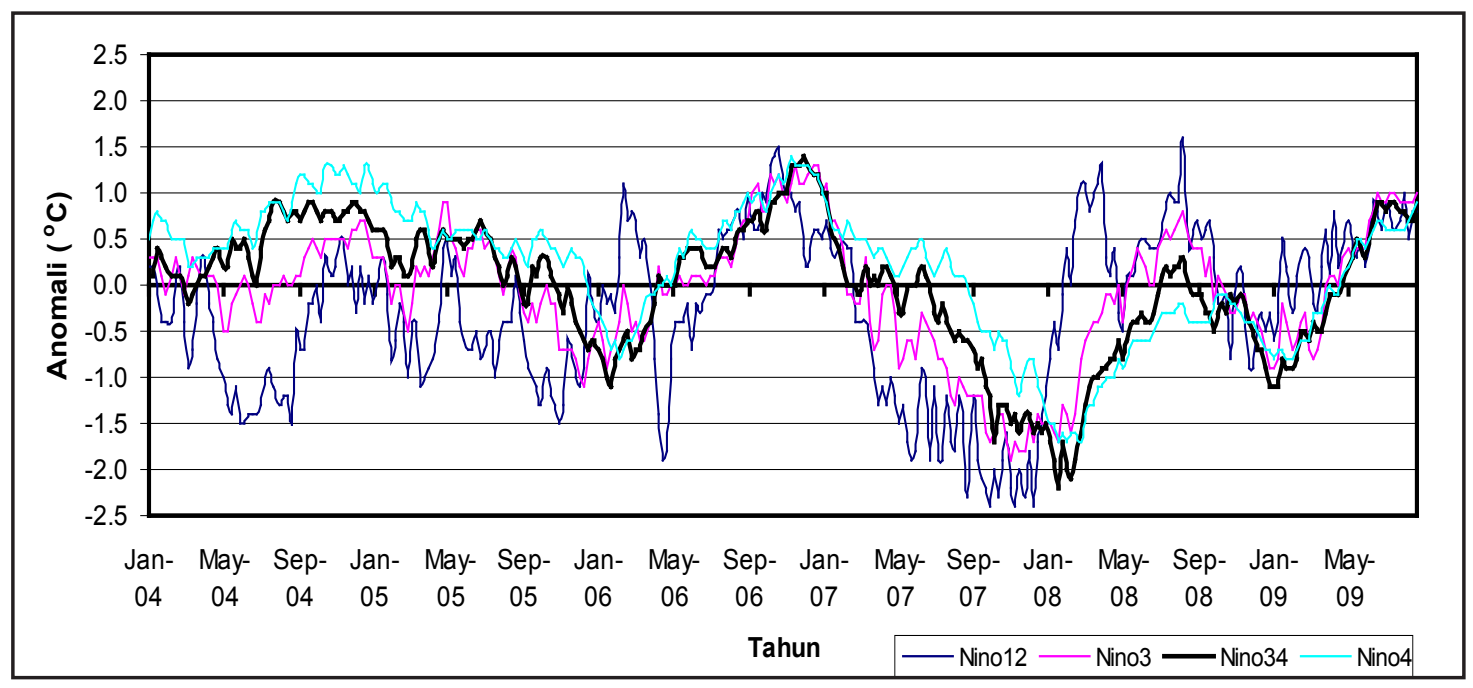

Gambar 4. Suhu Muka Laut (Sea Surface Temperature SST) daerah Nino selama lima tahun terakhir (sumber : http://www.cpc.ncep.noaa.gov/data/indices/wksst.for)

Nilai anomali SST untuk daerah Nino selama kegiatan TMC disajikan dalam Tabel1. Dari tabel terebut terlihat bahwa selama kegiatan TMC nilai anomali SST untuk keempat daerah Nino (Nino12, Nino3, Nino34 dan Nino4) adalah positif. Nilai rerata selama bulan Juli - Agustus 2009 tertinggi terdapat di daerah Nino3 sebesar $+0.93^{\circ} \mathrm{C}$. Dari nilai anomali tersebut menunjukkan bahwa selama kegiatan TMC kondisi global sudah memasuki fase EINino meskipun belum begitu kuat.

Kondisi EINino pada saat kegiatan TMC dilakukan mempengaruhi pertumbuhan awan yang sedikit dikarenakan uap air yang tersedia di atmosfer cukup kecil. Sebagian uap air di wilayah Indonesia akan tertarik ke arah timur menuju daerah Pasifik bagian timur.

Tabel 1. Nilai anomali SST untuk daerah Nino selama kegiatan TMC (Juli - Agustus 2009)

\begin{tabular}{|c|c|c|c|c|}
\hline Tanggal & $\begin{array}{c}\text { Nino } \\
12\end{array}$ & $\begin{array}{c}\text { Nino } \\
3\end{array}$ & $\begin{array}{c}\text { Nino } \\
34\end{array}$ & $\begin{array}{c}\text { Nino } \\
4\end{array}$ \\
\hline 1-Jul-09 & 0,6 & 0,9 & 0,9 & \\
\hline 8-Jul-09 & 0,9 & 0,9 & 0,8 & 0,6 \\
\hline 15-Jul-09 & 0,8 & 1,0 & 0,9 & 0,6 \\
\hline 22-Jul-09 & 0,6 & 1,0 & 0,9 & 0,6 \\
\hline 29-Jul-09 & 0,7 & 0,9 & 0,8 & 0,6 \\
\hline 5-Aug-09 & 1,0 & 0,9 & 0,8 & 0,6 \\
\hline 12-Aug-09 & 0,5 & 0,9 & 0,7 & 0,7 \\
\hline 19-Aug-09 & 0,8 & 0,9 & 0,7 & 0,8 \\
\hline 26-Aug-09 & 0,8 & 1,0 & 0,9 & 0,9 \\
\hline Rerata & $\mathbf{0 , 7 4}$ & $\mathbf{0 , 9 3}$ & $\mathbf{0 , 8 2}$ & $\mathbf{0 , 6 8}$ \\
\hline
\end{tabular}

\subsection{Suhu Muka Laut Daerah Sumatera Bagian Barat}

Profil suhu muka laut daerah Sumatera Bagian Barat selama tahun 2009 disajikan dalam Gambar 5. Dari gambar tersebut dapat dilihat bahwa selama tahun 2009 nilai suhu muka laut bervariasi di antara nilai $28.6^{\circ} \mathrm{C}$ sampai $30.4^{\circ} \mathrm{C}$ dengan tendensi mulai bulan Januari sampai dengan bulan Agustus mengalami peningkatan. Meskipun demikian pada awal bulan Juli terjadi penurunan cukup tajam dan naik kembali pada awal bulan Agustus.

Secara umum sejak awal bulan April 2009 nilai suhu muka laut berada di atas rerata dari normalnya, hal ini bisa dilihat dari nilai anomali suhu muka laut yang bernilai positif sejak awal bulan tersebut.

\subsection{Kondisi SOI}

Kondisi nilai SOI baik untuk equatorial SOI maupun Darwin-Tahiti SOI selama lima tahun terakhir disajikan dalam Gambar 5. Selama lima tahun terakhir kondisi nilai SOI berfluktuasi antara nilai posisif dan negatif, sehingga terlihat bahwa fenomena El Nino maupun La Nina mengalami periodisitas. Sejak bulan September 2008 nilai SOI (baik equatorial maupun Darwin-Tahiti) berada pada nilai posisif dan mencapai maksimum pada bulan Januari 2009. 


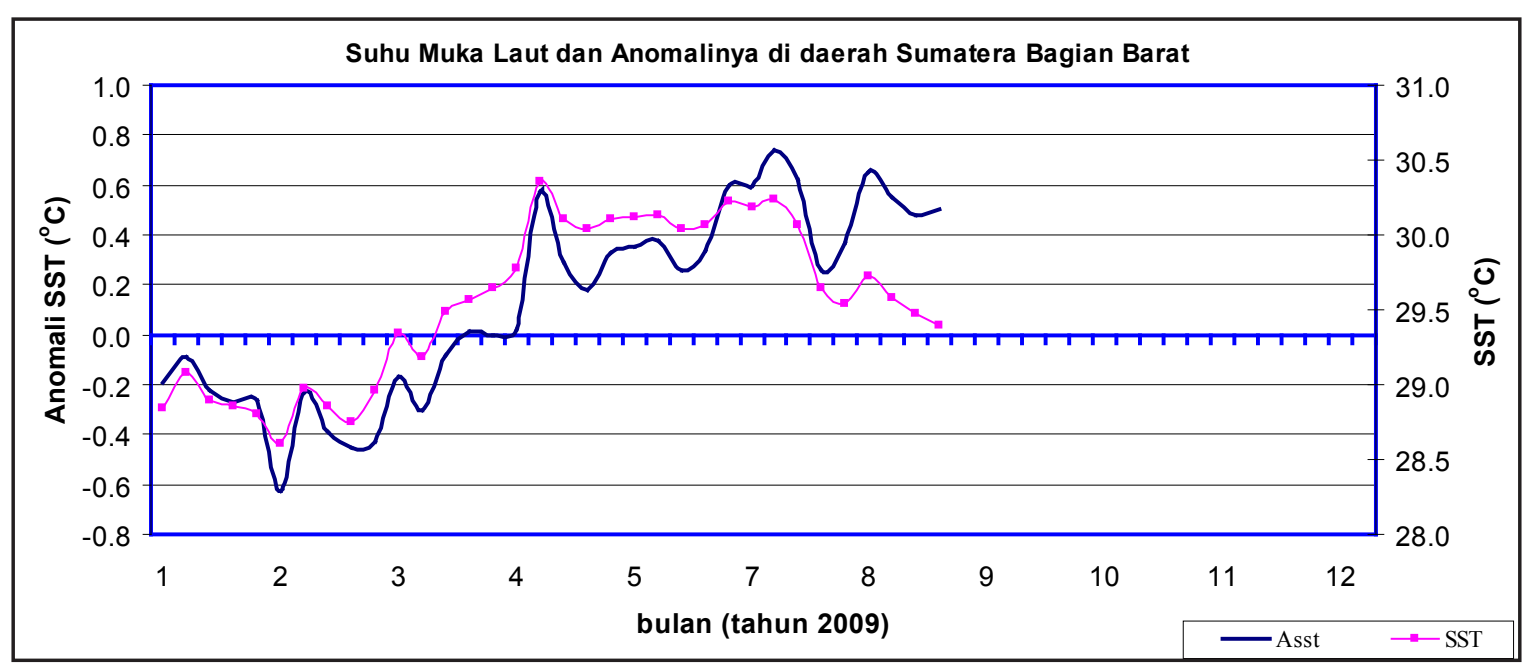

Gambar 5. Profil Suhu muka laut dan nilai anomalinya di wilayah daerah Sumatera bagian Barat. (diolah dari sumber data : http://dss.ucar.edu/datasets/ds277.0/)

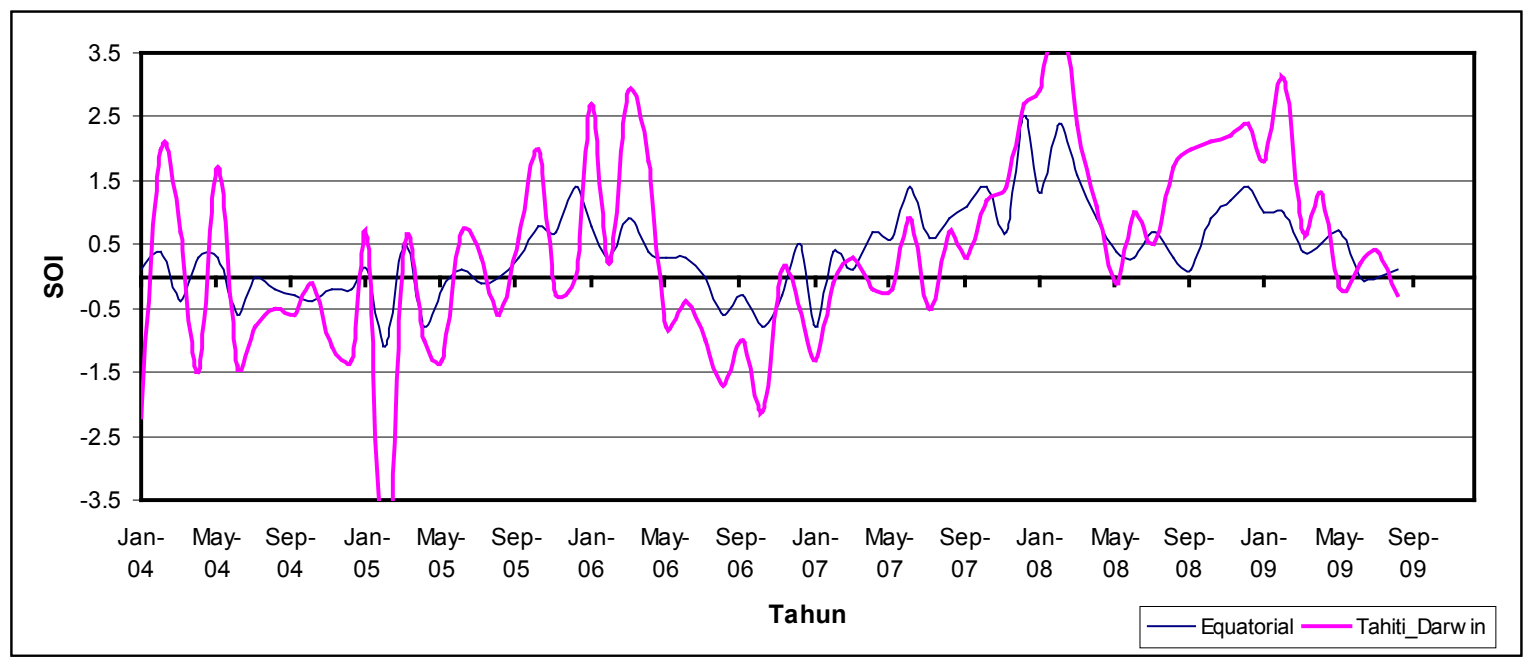

Gambar 6. Profil Equatorial SOI dan Tahiti-Darwin SOI selama lima tahun terakhir (sumber : http:/ www.cpc.ncep.noaa.gov/data/indices/reqsoi.for)

\subsection{Pengaruh Dipole Mode selama Kegiatan TMC}

Profil Diple Mode Index (DMI) selama tahun 2009 disajikan dalam Gambar 7. Selama kegiatan teknologi modifikasi cuaca dilaksanakan, pada awal bulan Juni nilai DMI menunjukkan adanya penurunan dari positif $(+)$ menuju kea rah netral, menjelang bulan Agustus nilainya menunjukkan adanya kanaikan kearah positif $(+)$ dan bertahan sampai akhir agustus 2009. Hal ini menunjukkan bahwa selama kegiatan teknologi modifikasi cuaca kondisi pertumbuhan awan di wilayah Indonesia bagian barat akan berkurang dari normalnya.

\subsection{Kondisi curah hujan daerah target selama kegiatan TMC}

Hasil penerapan Teknologi Modifikasi Cuaca
(TMC) dalam bentuk curah hujan untuk DAS Singkarak dan DAS Kotapanjang disajikan dalam Gambar 8. Dari gambar tersebut dapat dilihat bahwa untuk kedua DAS hampir tidak terdapat curah hujan yang signifikan kecuali pada tanggal 25 sampai dengan28 Juli 2009.

Jumlah curah hujan selama kegiatan untuk dua DAS yang terukur sekitar $16.5 \mathrm{~mm}$ (DAS Singkarak) dan $81 \mathrm{~mm}$ (DAS Kotapanjang). Selama 20 hari kegiatan jumlah hari hujan untuk DAS Singkarak hanya 8 hari (di Indonesia, hari hujan ditandai dengan curah hujan lebih besar atau sama dengan $0,5 \mathrm{~mm}$ dalam waktu 24 jam), sementara untuk DAS Kotopanjang hanya 7 hari.

Di DAS Kotapanjang selama kegiatan hanya mendapatkan 3 hari yang curah hujannya cukup signifikan (di atas $15 \mathrm{~mm} /$ hari) sedangkan untuk DAS Singkarak sama sekali tidak ada curah hujan yang melebihi $25 \mathrm{~mm} / \mathrm{hari}$. 


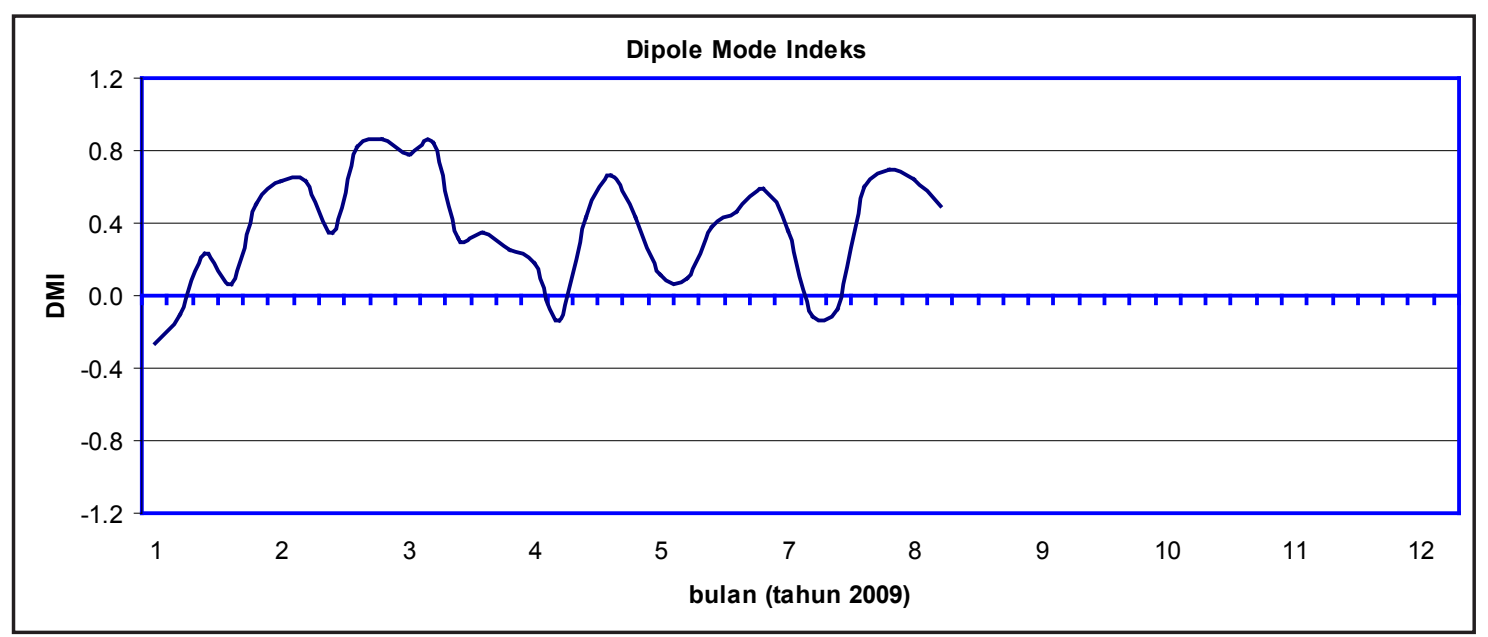

Gambar 7. Dipole mode indeks (DMI) selama tahun 2009 (diolah dari sumber data : http: dss.ucar.edu/datasets/ds277.0/)

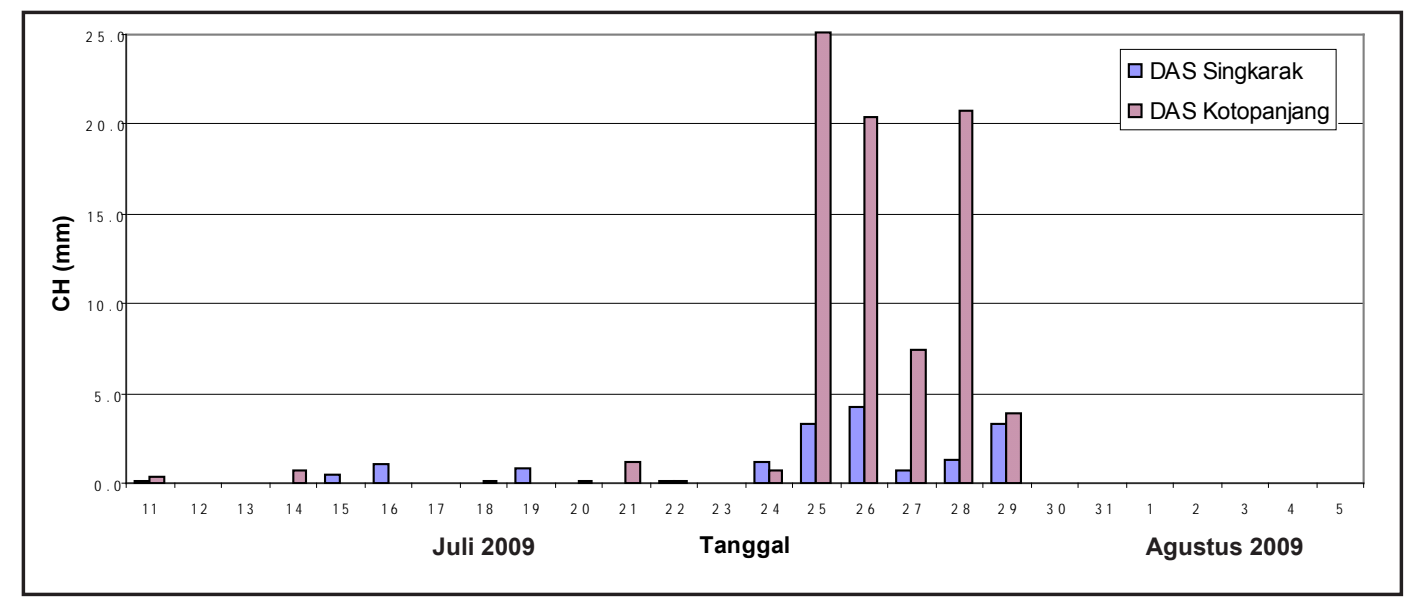

Gambar 8. Rerata curah hujan DAS Singkarak dan DAS Kotapanjang selama kegiatan TMC tanggal 16 Juli sampai dengan 4 Agustus 2009 yang diukur dari beberapa lokasi penakar (sumber data : UPT Hujan Buatan BPPT). dss.ucar.edu/datasets/ds277.0/)

Dari hasil di atas memberi pengertian bahwa selama kegiatan TMC kondisi atmosfer kedua DAS cukup kering sehingga sangat sulit untuk mendapatkan awan-awan yang potensial untuk disemai.

Selain itu dari hasil pengamatan secara sinoptik juga teridentifikasi adanya badai siklon tropis (Tropical Cyclone) yang berada wilayah timur Filipina. Keberadaan badai tropis tersebut semakin mengurangi jumlah uap air yang berada di daerah target, sehingga secara umum kondisi atmosfer tersebut kurang mendukung untuk pelaksanaan Teknologi Modifikasi Cuaca.

\section{KESIMPULAN}

Selama kegiatan Teknologi Modifikasi Cuaca (TMC) dilaksanakan nilai anomaly SST untuk ke- empat daerah Nino (Nino12, Nino3, Nino34 dan Nino4) adalah positif. Nilai rerata tertinggi terdapat di daerah Nino3 sebesar $+0.93^{\circ} \mathrm{C}$, dari nilai anomaly tersebut menunjukkan bahwa selama kegiatan TMC kondisi global sudah memasuki fase El Nino meskipun belum begitu kuat. Nilai suhu muka laut di wilayah Barat Sumatera bervariasi diantara nilai $28.6^{\circ} \mathrm{C}$ sampai dengan $30.4^{\circ} \mathrm{C}$ dengan tendensi mengalami peningkatan. Secara umum sejak awal bulan April 2009 nilai suhu muka laut di wilayah itu berada di atas rerata dari normalnya. Sejak bulan September 2008 nilai SOI (baik equatorial maupun Darwin - Tahiti) berada pada nilai positif dan mencapai maksimum pada bulan Januari 2009. Hasil analisis menunjukkan bahwa selama kegiatan TMC kondisi atmosfer kedua DAS cukup kering dan sangat sulit untuk mendapatkan awanawan yang potensial untuk disemai. 


\section{DAFTAR PUSTAKA}

National Weather Service, Climate Prediction Center, NOAA : Weekly Optimum Interpolation Sea Surface Temperature (SST) data, diakses dari situs http://www cpc.ncep.noaa.gov/da ta/indices/wksst.for

NCEP Version 2.0 Ol Global SST and NCDC Version 3.0 Extended Reconstructed SST Analyses dataset

Reynolds, R.W., N.A. Rayner, T.M. Smith, D.C. Stokes, and W. Wang, 2002: An Improved In Situ and Satellite SST Analysis for Climate. J. Climate, 11, 3320-3323.

Smith, T.M., R.W. Reynolds, Thomas C. Peterson, and Jay Lawrimore, 2007: Improvements to NOAA's Historical Merged Land Ocean Surface Temperature Analysis (1880-2006). J. Climate, 21(10), 2283-2296 (DOI: 10.1175/2007JCLI21 00.1).
Syaifullah, D., D. Gunawan, 1999: Variasi SST \& SOI Terhadap Kejadian El-Nino \& LaNina di Wilayah Indonesia, Prosiding Konferensi Energi, Sumberdaya Alam dan Lingkungan (ESDAL). Jakarta.

UPT Hujan Buatan, Laporan Hasil Kegiatan Pekerjaan Hujan Buatan / Teknologi Modifikasi Cuaca (TMC) di Catchment Area PLTA Singkarak, Maninjau PT. PLN (persero) Pembangkitan Sumatera Bagian Selatan Sektor Pembangkitan Bukittinggi dan PLTA Kotopanjang PT. PLN (Persero) Pembangkitan Sumatera Bagian Utara Sektor Pembangkitan Pekanbaru 16 Juli s.d 04 Agustus 2009, Jakarta, 2009. 
